\title{
THE ENVIRONMENTAL ASSET OF THE RURAL FROM ORADEA METROPOLITAN AREA (ROMANIA)
}

\author{
Ribana LINC* \\ University of Oradea, Department of Geography, Tourism and Territorial Planning, \\ University St., 410087, Oradea, Romania e-mail: ribanalinc@yahoo.com \\ Iulian DINC $\breve{A}$ \\ University of Oradea, Department of Geography, Tourism and Territorial Planning, \\ University St., 410087, Oradea, Romania, e-mail: iulian_dinca@yahoo.co.uk \\ Stelian NISTOR \\ University of Oradea, Department of Geography, Tourism and Territorial Planning, \\ University St., 410087, Oradea, Romania e-mail: snistor@uoradea.ro

\section{Corina TĂTAR} \\ University of Oradea, Department of Geography, Tourism and Territorial Planning, \\ University St., 410087, Oradea, Romania, e-mail: corina_criste 78@yahoo.com
}

\section{Liviu BUCUR}

University of Oradea, Department of Geography, Tourism and Territorial Planning, University St., 410087, Oradea, Romania, e-mail: liviubucur@yahoo.com

\section{Marcu STASAC}

University of Oradea, Department of Geography, Tourism and Territorial Planning, University St., 410087, Oradea, Romania, e-mail: marcu_stasac@yahoo.com

\section{Marius I. STUPARIU}

University of Oradea, Department of Geography, Tourism and Territorial Planning, University St., 410087, Oradea, Romania e-mail: marius stupariu@yahoo.co.uk

Citation: Linc, R., Dincă, I., Nistor, S., Tătar, C., Bucur, L., Staşac, M., Stupariu I.M. (2019). The Environmental Asset of the Rural from Oradea Metropolitan Area (Romania). Analele Universităţii din Oradea, Seria Geografie, 29(2): 01-17. https://doi.org/10.30892/auog.292101-816

\begin{abstract}
Starting from one of the main objectives of constitution of Oradea Metropolitan Area (O.M.A.) namely to ensure the continuous increase of live quality, the aim of the study is the highlight and analysis of high value natural resources, natural reserves and Natura 2000 sites and also to ensure the quality of environmental factors for the touristic use. The importance of protection and conservation of some natural elements also results from the fact that the surface of natural reserves within O.M.A. increases from $6.25 \%$ of overall surface of natural reserves of Bihor county, prior the integration in the E.U., to $24.3 \%$ after the European
\end{abstract}


integration, after the implementation of Natura 2000 ecological network. One can identify nine Natura 2000 sites within O.M.A., which includes two SPA and seven SCI sites. The analysis of the environmental factors (air, surface and underground waters) shows that the physical and chemical parameters are within the legal range without threatening the communities and the natural resources with touristic potential.

Key words: Oradea Metropolitan Area, natural protected areas, Natura 2000, quality of environmental elements, biodiversity, environmental touristic potential

$* \quad * \quad * \quad * \quad * \quad *$

\section{INTRODUCTION}

In its simplest meaning, the biodiversity is "the sum of all living creatures from the Earth, linked by abiotic components of the planet such as: atmosphere, oceans, fresh waters, geology, soils". All forms the "biosphere" (biologyreference.com, Friedman, 2010). Secondary, the biodiversity of an area also supply a set of ecological services, represented by fresh water, protection of local communities by natural disasters, food and raw materials supply a.s.o. In the broadest sense, we can also add that the biodiversity favourise the progress of touristic activity.

Restraining the ideas to local scale, the analysis will focuses on Oradea Metropolitan Area (O.M.A.). The general objective of the 12 administrative components (Oradea municipium and Biharia, Cetariu, Paleu, Ineu, Oşorhei, Sînmartin, Nojorid, Sîntandrei, Toboliu, Girişu de Criş and Borş communes) is represented by increasing the living standards by using the existing resources and promoting the natural potential. We consider that two of the main resources of O.M.A. are given by the protected areas (natural reserves and Natura 2000 sites) and the good quality of environmental factors.

The aim of the study is to highlight these two resources in two ways:

- the real possibility that these two resources to get into attention of local administration by a qualitative and quantitative integration of the information into management plans but also for future investors who are interested in a sustainable use of the local environment;

- the care for increasing the living standards of the inhabitants of O.M.A. through possible popularization activities but also through the increase of consciousness of the individuals and communities who take care of the environment.

The question of relevance of living environment compared to the ecosystem balance of the protected areas, the human impact, the increase of local inhabitants awareness are found in some studies (Ilieș et al., 2017a; Ilieș et al., 2017b; Wendt et al., 2019). An other study (Tătar et al., 2018) deals with the opportunities offered by natural environment for touristic activities but the protected areas were just tangentially analysed.

\section{MATERIALS AND METHODS}

The methodological analysis was oriented towards two main directions: collecting and analysis of quantitative and qualitative information from references and the field survey. The analysis of references comes from references which deals the topic related to analysis of O.M.A. and Bihor county but also online sources. The field survey focused on: the geomorphological, biogeographical, hydrological, landscape analysis; the analysis of environmental factors and components focusing on the analysis of dynamic evolution for each commune; analysis of detailed survey images acquired by Phantom 4 DJI drone images in order to observe the effects of human intervention upon protected areas.

The quantitative and qualitative data and the field surveys were previously analysed in detail. ${ }^{1}$ Within the quantitative analysis, for "Point A. Natural touristic resources", for the criteria

\footnotetext{
${ }^{1}$ https://lege5.ro/../metodologia-pentru-analiza-potentialului-turistic-al-teritoriului-din-..
} 
"Natural protected areas" (total number of 5 points) was taken into consideration the following aspects for each commune within O.M.A.: degree of representativity of the protected area (max. 1 point), the total surfacsitee of protected area (as percentage from the administrative territory, max. 1 point), degree of conservation and the present state of the reserve (max. 1 point), the landscape value of the protected area (max. 1 point), the possibility of practicing different form of tourism (max. 1 point).

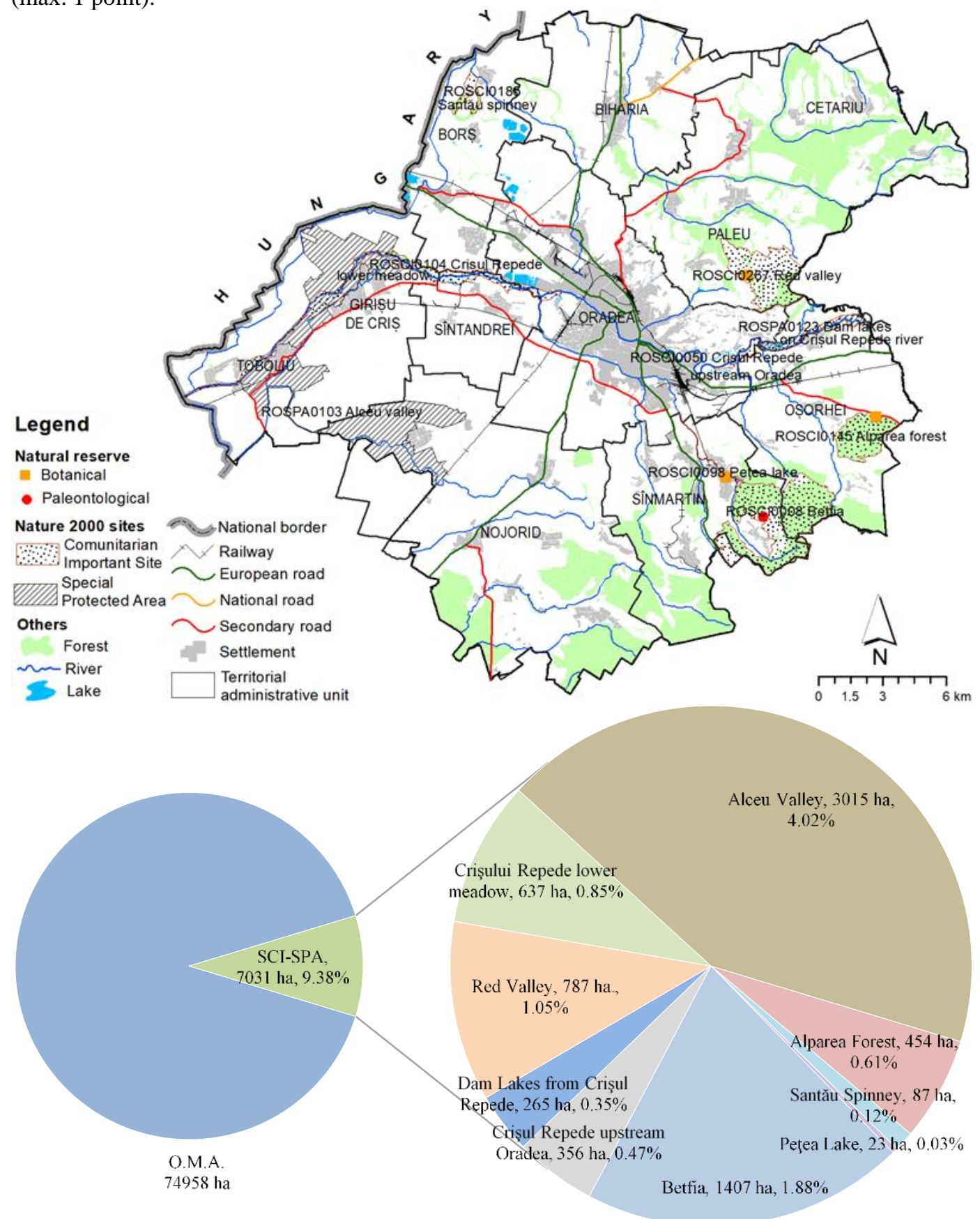

Figure 1. Protected areas of Oradea Metropolitan Area (O.M.A) 


\section{RESULTS}

\section{Natural Protected Areas}

Uniqueness, scientific importance, danger of extinction, representativity, utility were sets of priorities for protection and conservation of some elements of the natural environment. Thus, within the territory of O.M.A., prior the E.U. adherence, were four natural reserves $(6.25 \%$ of overall protected area surface of Bihor county $)^{2}$ : Peţa brook Botanical Reserve (4 ha), Şomleu Hill Paleontological Reserve (5 ha), both located within Sînmartin commune administrative territory, Daffodils Forest from Alparea Botanical Reserve (Oșorhei commune, 2 ha), Meadows from Red Valley Botanical reserve (4 ha, Săldăbagiu de Munte village, Paleu commune).

After the integration in the E.U., the Natura 2000 ecological network was created, with two major components, S.C.I. (Sites of Community Importance) and S.P.A. (Special Protected Areas). Within O.M.A., nine Natura 2000 sites were created $(24.3 \%$ of overall protected area of Bihor county), two S.P.A. sites and seven S.C.I. sites (figure 1), with a total area of 7,031 ha (9.38\% of O.M.A. total area). Seven Natura 2000 sites already have Management Plans and for two sites (ROSCI0185 Santău Spinney and ROSCI0267 Red Valley) just standard information sheet is available.

Table 1. The score of each Natura 2000 site

according to Methodology of evaluation of touristic potential in territorial and administrative units, Annex A

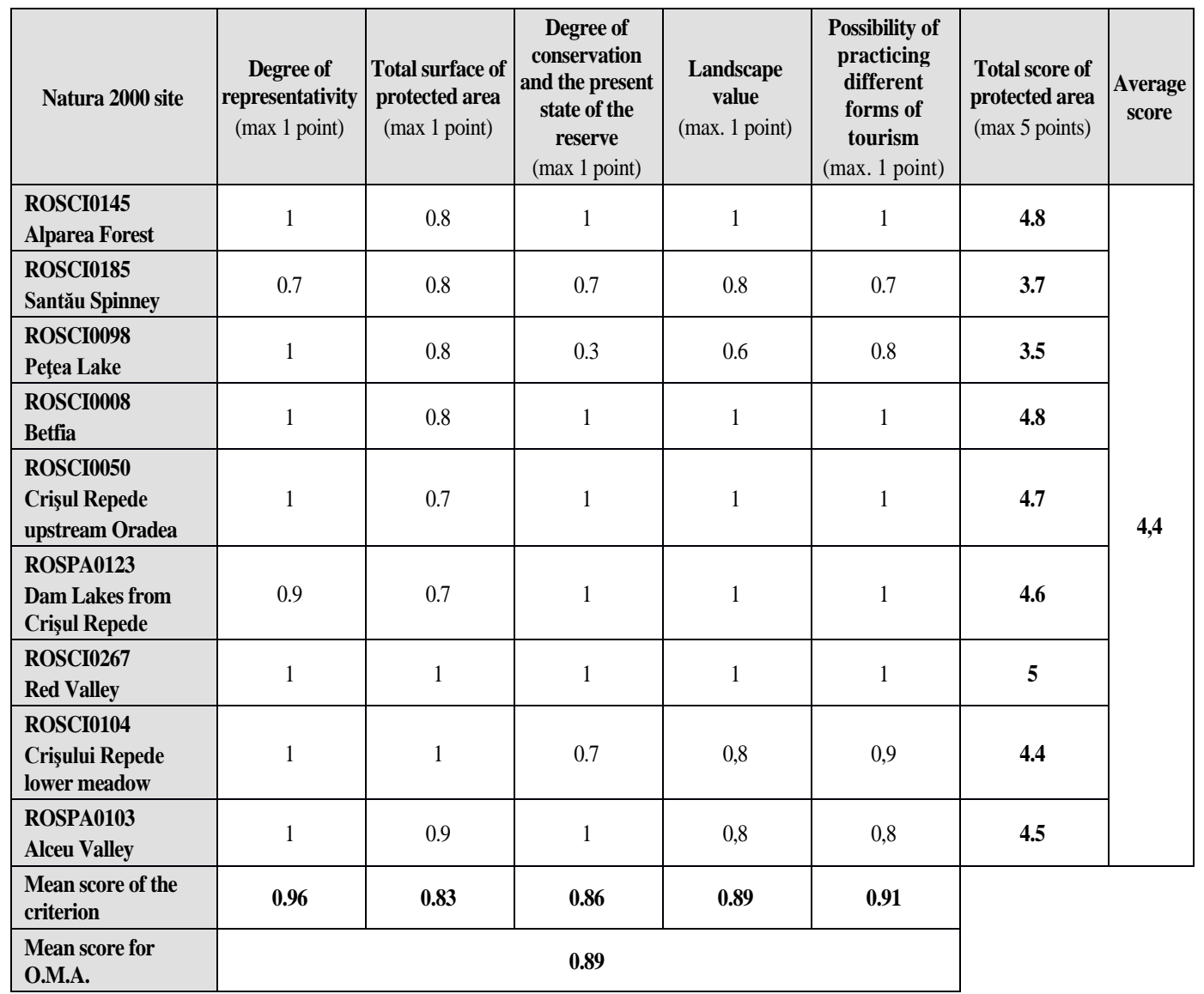

\footnotetext{
${ }^{2}$ In Bihor county are officially designated 64 natural reserves of national interest, 13 of local interest, 37 Natura 2000 sites (9 S.P.A., 28 S.C.I. sites) and two natural parks (Cefa Natural Park, 5,002 ha, located in the vicinity of O.M.A. and Apuseni Natural Park, which covers three counties, 64,000 ha)
} 


\section{Alparea Forest Natura 2000 ROSCI0145 site}

For degree of representativity subcriterion the site is granted with the maximum value, 1 point, because the site includes in the northern part the Daffodils Forest from Alparea Botanical Reserve (I.U.C.N. III category), proposed for conservation since 1984 by Marrosy Anna, currently being a protected area of national importance (Tuduce et. al., 2001).Here, one can find Narcissus poeticus ssp. Radiiflorus, located at one of the lowest altitudes in Romania and also being at the edge of ecological optimum.

For overall protected surface subcriterion (as part of overall administrative surface) the site is granted with 0.8 . The protected area covers 459 ha, located over the administrative territory of two communes, just Oșorhei commune being part of O.M.A. (the protected area covers 7\% from Oșorhei commune administrative territory, the rest being located in Copăcel commune, with less than 1\%).

For degree of conservation and current state of the reserve subcriterion the site is granted with 1 point. The daffodils appear in bunches or as isolated individuals (figure 2), the flowers cover areas more than few square meters just isolated. The ROSCI0145 Natura 2000 site was proposed for protection in order to preserve the forest habitats (oak mixed with sessile and hornbeam) and to protect three species of amphibians - Bombina bombina; Bombina variegata, Triturus cristatus, all three species being in a good conservation status. ${ }^{3}$
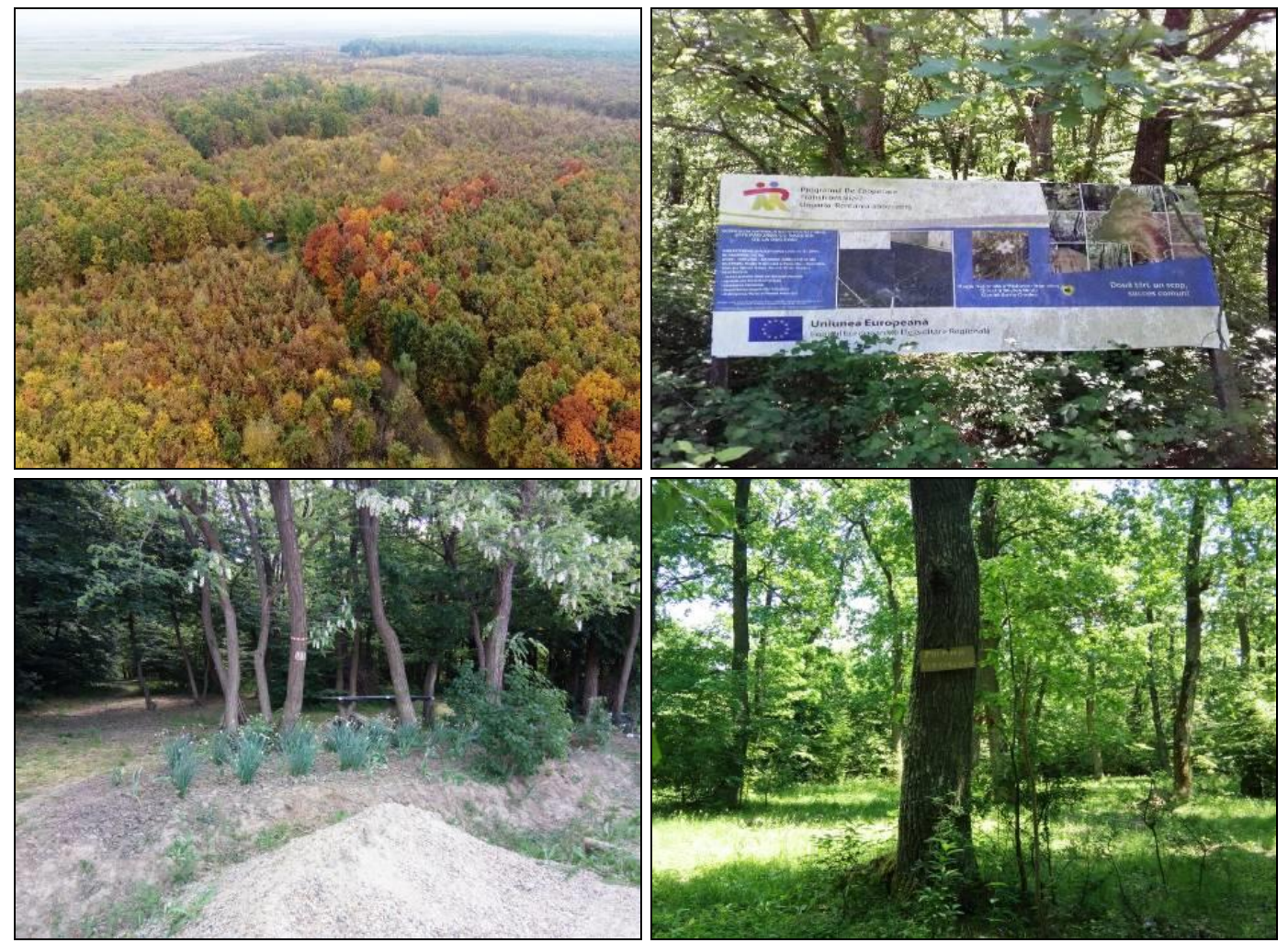

Figure 2. Alparea Forest Natura 2000 ROSCI0145 site

Left down, bunches of Narcissus poeticus ssp. Radifflorus blossoming in May

For the landscape value of protected area subcriterion the site is granted with 1 point because the areas in a natural state are well preserved (compact forests, meadows, brooks, wild fauna, visible image elements, large volumes of green areas, structures generated by compact forest areas, viewing and opening axes sometimes limited but very suggestive).

\footnotetext{
${ }^{3}$ http://www.mmediu.ro/app/webroot/uploads/files/2015-09-21_ROSCI0145_Padurea_Alparea_Plan_management.pdf
} 
For the possibility of practicing different form of tourism subcriterion the site is granted with the maximum score, 1 point, because there are multiple possibilities for discovery and scientific forms of tourism which are supported by road network and meadows, allowing accessibility. figure 10).

Thus, the Alparea Forest Natura 2000 ROSCI0145 site is granted with 4.8 points (table 1,

\section{Santău Spinney Natura 2000 ROSCI0185 site}

For degree of representativity subcriterion the site is granted with 0.7 points because the site doesn't have any natural reserve within its territory.

For total surface of protected area subcriterion the site is granted with 0.8 points. The site in entirely within O.M.A., respectively, Borș commune, but occupies a small area (113 ha, respectively $2 \%$ of the commune's territory).

For degree of conservation and present state of the reserve subcriterion the site is granted with 0.7 points. The site has just "Standard Form" in which are presented just basic information about the site, namely that is an alluvial forest with Alnus glutinosa and Fraxinus excelsior, peat bogs, swamps, arable land, meadows and pastures (figure 3). which protects habitats with Salix alba, Populus alba, Alnus glutinosa, Fraxinus excelsior and also endangered/rare fauna elements such as fishes (Umbra krameri), amphibians, Bombina bombina, considered to be an vulnerable species, on the Red List of the I.U.C.N. ${ }^{4}$ In the "Standard Form" are also mentioned the vulnerability for illegal logging, draining's, agriculture, clogging.

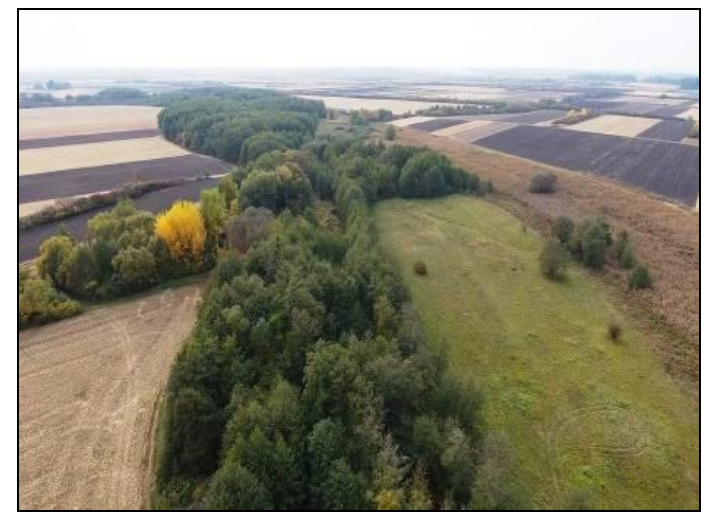

Figure 3. Santău Spinney Natura 2000 ROSCI0185 site

For landscape value subcriterion the site is granted with 0.8 point. One can find here a mosaic type landscape association between the green, natural part of the corridor and the agricultural land. For possibility of practicing different forms of tourism subcriterion the site is granted with 0.7 points. This value is supported by a limited number of persons involved in discovery and weekend forms of tourism. Thus, Santău Spinney Natura 2000 ROSCI0185 site totals a number of 3.7 points (table 1, figure 10).

\section{Peța Lake Natura 2000 ROSCI0098 site}

For degree of representativity subcriterion the site is granted with 1 point because it includes a famous for its endemisms nature reserve, namely Peţa lake Botanical Reserve (4 ha, within Sînmartin commune territory) which is famous for its three endemisms living in a subtropical type ecosystem, considered to be relicts from the last Ice Age: the thermal water lily (Nymphaea lotus var. Thermalis), thermal snail (Melanopsis parreyssi 'Moellendorff' Philippi -

\footnotetext{
${ }^{4}$ http://biodiversitate.mmediu.ro/rio/Natura2000/static/pdf/rosci0185.pdf
} 
1847) (recently re-evaluated as Microcolpia parreyssii), ${ }^{5}$ thermal rudd (Scardinius racovitzai Müller - 1958), but also other species of community interest.

For total surface of protected area subcriterion the site is granted with 0.8 points. The site is entirely located within O.M.A. but it covers just a small area (49 ha, just $0.1 \%$ of the Oradea surface and $0.4 \%$ from Sînmartin commune surface).

For degree of conservation and present state of the reserve/Natura 2000 site, the site is granted with 0.3 points. The small score can be explained by the fact that the site is in an ecological collapse. From 2011, the Peta Lake ecosystem is in a real ecological crisis for two reasons: the drastic reduction of the water level from the lake which led in 2012 and 2015 to a complete drying up and to a significant decrease of water temperature at about $11^{\circ} \mathrm{C}$ (far under the physiological needs of thermal species).

In situ, the thermal snail and the thermal rudd were declared extinct by the former custodian of the reserve. ${ }^{6}$ The rhizome and the seeds of the thermal water lily proved to be extremely resilient because in the summer of 2013 even in the summer of 2015 the flowers blossomed. Currently the plant survives in artificial pool condition in Băile Felix Spa but rarely individuals blossomed in Peta brook, outside the natural reserve but inside the area of the Natura 2000 site (figure 4). This species is a rare/endangered taxon which is not evaluated by I.U.C.N. The field survey made in 2015 for the Management Plan were identified a population of 77 individuals (33 individuals in the lake, the rest along the brook) ${ }^{7}$ (Orășeanu and Malancu, 2017; Orășeanu et al., 2017; Grigoraş et. al., 2015; Ilieş et. al., 2015; Linc and Staşac, 2015; Şoldea, 2003; Marossy, 1999; Oltean-Cosma, 1991; Borza, 1924. Also, worth mention that the water lily is nature monument and on the bank of the lake one can find an oak tree of about 300 years old.

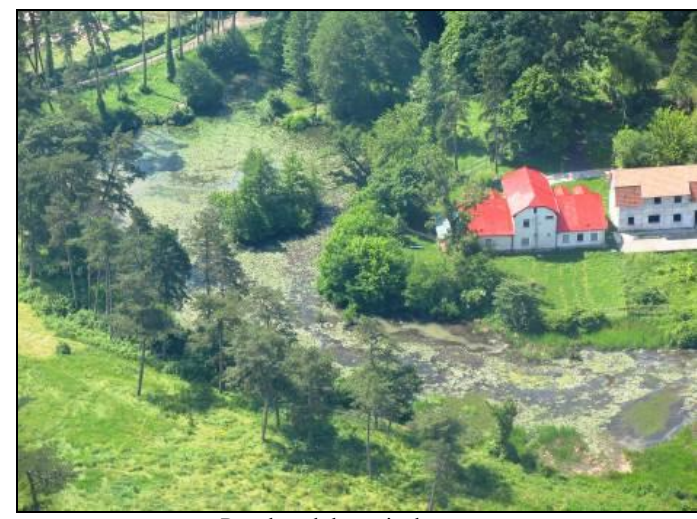

Peța brook botanical reserve

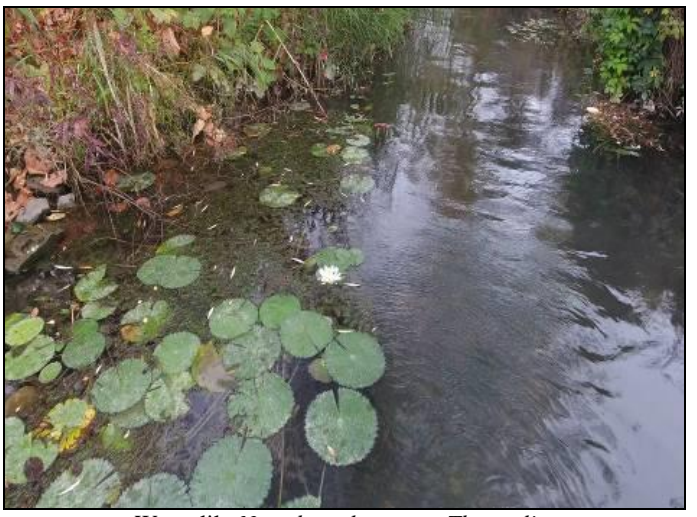

Water lily Nymphaea lotus var. Thermalis. The only in situ surviving species

Figure 4. Peța Lake Natura 2000 ROSCI0098 site

Peța Lake Natura 2000 ROSCI0098 site was declared protected area for Priority Habitat $31 A 0 *$ thermal waters from Transylvania covered by water lily but the present conservation state is heavily affected. Within the perimeter of the Natura 2000 site one can also find other protected species of community interest such as Unio crassus (resident, isolated, native and very rare population) and Chilostoma banaticum (resident, native and rare population), Rhodeus sericeus amarus (sedentary/resident population, marginal, native, with definite presence), Bombina variegata, Triturus cristatus, Bombina bombina, Emys orbicularis. ${ }^{8}$

\footnotetext{
${ }^{5}$ http://www.mmediu.ro/app/webroot/uploads/files/2016-04-11_PM_ROSCI0098_Petea.pdf

${ }^{6}$ There is currently a malfunction in the management of a protected area after the publication of O.U.G. 75/2018 because from the law disappears the custodian term and it is established the National Agency for Natural Protected Areas (A.N.A.N.P.)

${ }^{7}$ http://www.mmediu.ro/app/webroot/uploads/files/2016-04-11_PM_ROSCI0098_Petea.pdf

${ }^{8}$ Idem
} 
For the landscape value subcriterion the area is granted 0.6 points. Despite the fact that the rare species were not counted for the overall score, the landscape is attractive because of the huge size of the pine trees, because of the volumes of shrub associations with a marginal disposal around the lake and also because of the corridor effect of the Peța brook.

For the possibility of practicing different form of tourism subcriterion, the site granted 0.8 point, because of the vicinity of Băile Felix and Băile 1 Mai Spas which generates the visitor's flux and interest for discovery of the site.

Thus, the Peţa Lake Natura 2000 ROSCI0098 site totals a number of 3.5 points (table 1 , figure 10).

\section{Betfia Natura 2000 ROSCI0008 site}

Because the site includes Şomleu Hill paleontological reserve, well known for the fossils discovered here, the site granted 1 point. Şomleu Hill (figure 5) is well known in the international scientific literature because fossil site no. 2 represents a typical phase of the Lower Pleistocene, dated 1.4-1.6 mil years ago. From the 13 fossil sites were excavated 200 species of vertebrates, for ex. a species of bird Palergosteon tothi, amphibians Pliobatrachus langhae, Parahynobius betfianus and also a high variety of terrestrial microfauna. ${ }^{9}$

For the total surface of protected area subcriterion the site granted 0.8 point. The site covers 1,748 ha, located within three communes, two of them being situated within O.M.A. (Sînmartin: 14.2\%, Oşorhei (8.2\%), Hidişelu de Sus (3\%).

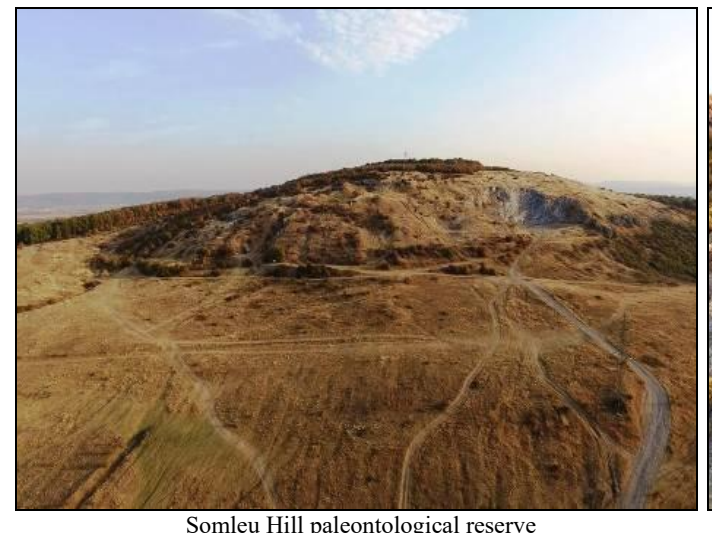

Şomleu Hill paleontological reserve

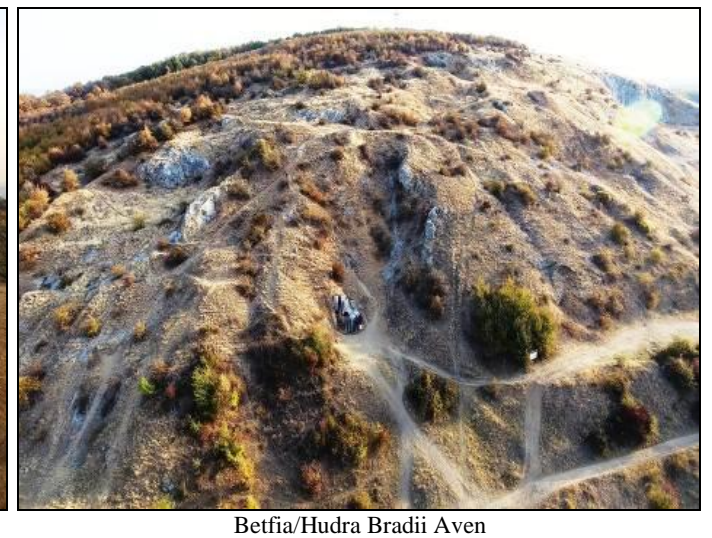

Betfia/Hudra Bradii Aven

Figure 5. Betfia Natura 2000 ROSCI0008 site

For degree of conservation and present state of the reserve subcriterion the site granted 1 point. The northern and eastern slopes of the hill are covered by ash, linden, wild cherry trees. Among the protected species one can find Ruscus aculeatus, with a population of about 500 individuals in a high degree of conservation although it is harvested because of its curative qualities and as ornamental plant. Inside Betfia Aven one can find bat colonies, Myotis blythii, Myotis myotis și Miniopterus schreibersii species, with a population of about 11,000 individuals. Reptilian are also numerous, the most common species being Elaphe longissima, Vipera berus, Lacerta viridis. The bird species are represented by Buteo buteo, Oenanthe oenanthe, Lanius minor, Lanius excubitor a.s.o. ${ }^{10}$

The landscape value of the site subcriterion is granted 1 point. Because the area is a mixture of geomorphological features which belongs to endo (aven) and exokarst mixed with mature forest and shrub associations. For possibility of practicing different forms of tourism

\footnotetext{
${ }^{9}$ http://www.mmediu.ro/app/webroot/uploads/files/2016-04-11_PM_ROSCI0008_Betfia.pdf 
subcriterion the site granted 1 point. The spas located in the vicinity of the site supply a constant visitor's flux for different types of tourism. Thus, the Betfia Natura 2000 ROSCI0008 site totals 4.8 points (table 1 , figure 10 ).

\section{Crişul Repede upstream of Oradea Natura 2000 ROSCI0050 site}

For degree of representativity subcriterion the site granted 1 point. It doesn't include any natural reserve; it is a Site of Community Importance (S.C.I.) but includes special protection site (Dam Lakes from Crișul Repede ROSPA0123 site).

For total surface of protected area subcriterion the site granted 0.7 point. It covers 2,006 ha but within O.M.A. is just Oşorhei commune (just $2.7 \%$ being under protection of the overall area), Ineu $(1.5 \%)$, Oradea $(0.9 \%)$, the rest being divided among the territory of other nine communes.

For degree of conservation and present state of the reserve subcriterion the site granted 1 point. Along Crișul Repede river, in both protected areas, one can find alluvial forests with Alnus glutinosa and Fraxinus excelsior which host a high variety of protected species such as Unio crassus, Barbus meridionalis, Lutra lutra which has stable populations. ${ }^{11}$

For landscape value subcriterion the site granted 1 point. The high score can be related by the value and diversity of the existing natural elements, the course of Crișul Repede river, Fughiu Lake (figure 6), the dam lakes, King's Land și Camelot recreational lakes, the forests and the elongated Oradiei Hills.
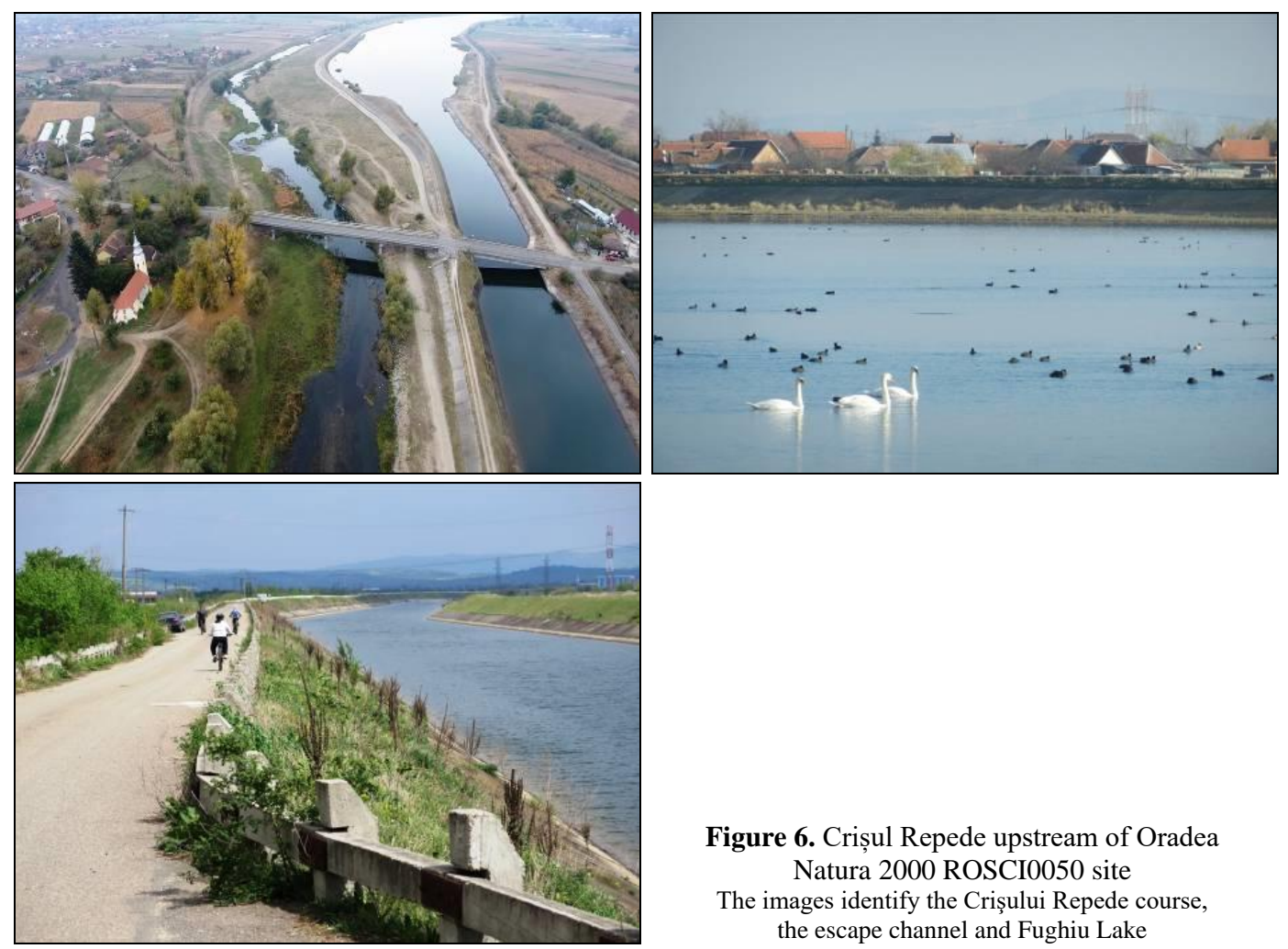

Figure 6. Crișul Repede upstream of Oradea Natura 2000 ROSCI0050 site

The images identify the Crişului Repede course, the escape channel and Fughiu Lake

Discovery tourism, horse ridding, sport fishing and adventure tourism (with light aircrafts) are different forms of tourism which granted the area 1 point.

Thus, the Crişul Repede upstream of Oradea Natura 2000 ROSCI0050 site totals 4.7 points (table 1, figure 10).

\footnotetext{
${ }^{11}$ http://www.mmediu.ro/app/webroot/uploads/files/2016-03-22_PM_REG_ROSCI0050_ROSPA0123.pdf
} 


\section{Dam Lakes from Crişul Repede Natura 2000 ROSPA0123 site}

For degree of representativity subcriterion the site granted 0.9 point because it is included in a Site of Community Interest (Crişul Repede upstream of Oradea Natura 2000 ROSCI0050 site).

For total surface of protected area subcriterion the site granted 0.7 point. It covers 1,118 ha which overlap nine administrative units, just Oşorhei $(2.7 \%)$, Ineu $(1.5 \%)$ and Oradea $(0.2 \%)$ being within O.M.A.

For degree of conservation and present state of reserve/Natura 2000 site subcriterion the site granted 1 point. The habitats are important for bird populations mentioned in Annex 1, 79/409/CEE such as Nycticorax nycticorax, Egretta alba, Ciconia nigra, Ciconia ciconia, Lanius collurio, Aythya nyroca. The site is also important for other species of birds unmentioned in Annex 1 such as Ardea cinerea, Larus ridibundus, Gallinula chloropus, Vanellus vanellus. The natural eutrophic lakes with Magnopotamion or Hydrocharition are feeding and sheltering habitats for many fish and invertebrates species. ${ }^{12}$

For landscape value subcriterion the site granted 1 point because of the high degree of representativity of lakes and because of the high diversity of fresh water fauna, which are the main attraction elements.

For possibility of practicing different forms of tourism subcriterion the site granted 1 point because of the various tourist form opportunities - bird watching, sport angling, cycling.

Thus, Dam Lakes from Crişul Repede Natura 2000 ROSPA0123 site totals 4.6 points (table 1, figure 10).

\section{Red Valley Natura 2000 ROSCI0267 site}

For degree of representativity subcriterion the site granted 1 point because it overlaps the Red Valley Grassland botanical reserve (4 ha, east of Săldăbagiu de Munte village).

For total surface of protected area subcriterion the site granted 1 point because it covers upon the following administrative units: Paleu (15\%) Oradea (0,1\%), Oşorhei (0.1\%), Ineu (1.4\%), all members of O.M.A. This site protects an area of 819 ha.
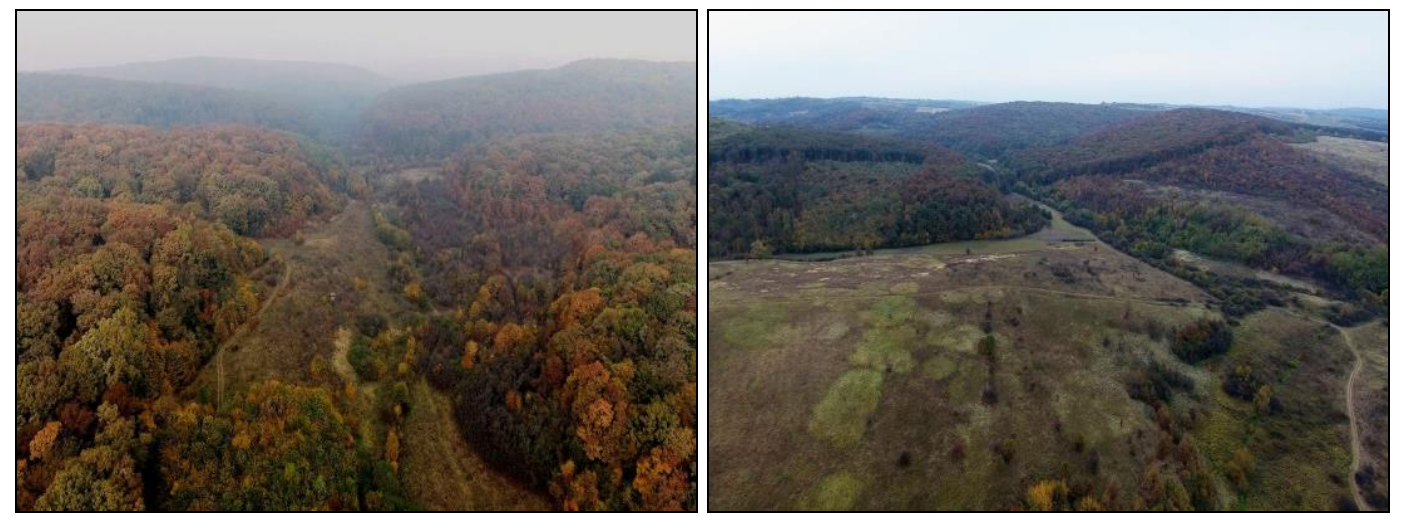

Figure 7. Red Valley Natura 2000 ROSCI0267 site

For degree of conservation and present state of reserve/Natura 2000 site subcriterion the site granted 1 point although the score is granted reticently. ${ }^{13}$ The site is covered by beech forests (Asperulo-Fagetum). Within the site one can find 14 plant species which are on the Red List together with amphibians and reptiles. The site is supposed to illegal logging. A part of the site overlaps Red Valley Grassland botanical reserve which is consisted of grasslands, deciduous forest

\footnotetext{
${ }^{12}$ http://www.mmediu.ro/app/webroot/uploads/files/2016-04-11_PM_ROSCI0098_Petea.pdf

${ }^{13}$ This Natura 2000 site doesn have a Management Plan. We noticed during the field survey that the information from the Standard Form are not confirmed on the field.
} 
which host some protected species such as Salvia amplexicaulis, Rhinanthus borbasii (Corydalis solida ssp. slivenensis) a.s.o. ${ }^{14,15,16}$ (Herman et. al., 2016; Ilieş et. al., 2017).

For landscape value of natural protected area subcriterion the site granted 1 point, because of the relevance of forest associations, grassland and shrub associations, the brook, as dominant attractiveness elements (figure 7) to which is added the elongated geometry of the hills and of the brook.

For possibility of practicing different forms of tourism subcriterion the site granted 1 point because of the high degree of accessibility and the richness of natural elements which can support different types of discovery, scientific, tourism, cyclo-tourism a.s.o.

Thus, Red Valley Natura 2000 ROSCI0267 site totals 5 points (table 1, figure 10).

\section{Crişului Repede lower meadow Natura 2000 ROSCI0104 site}

For degree of representativity subcriterion the site granted 1 point because partially overlap (42\%) Valea Alceului ROSPA0103 site.
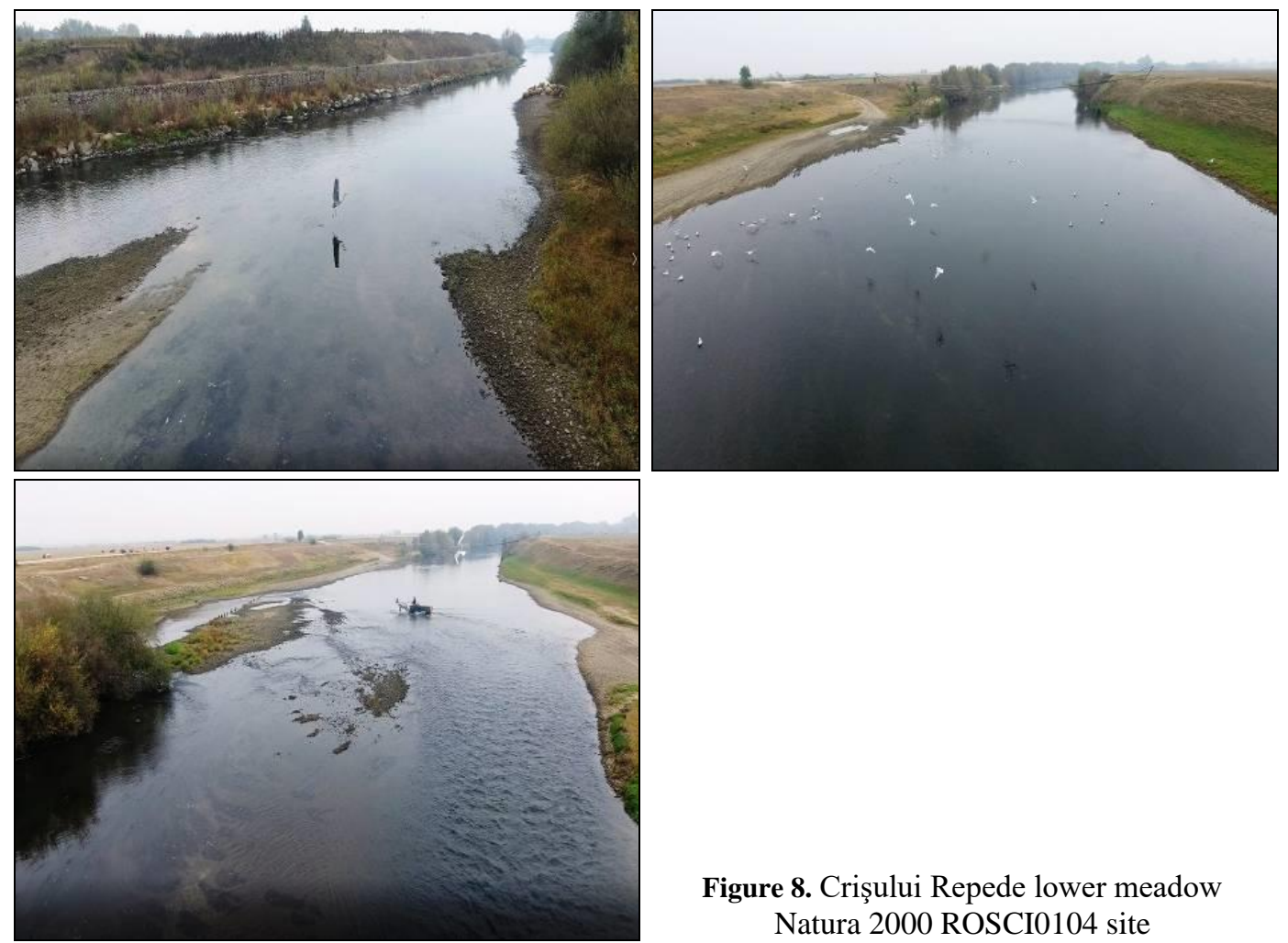

Figure 8. Crişului Repede lower meadow Natura 2000 ROSCI0104 site

For total surface of protected area subcriterion the site granted 1 point because the site covers 844 ha located entirely within O.M.A. (Borş: 0.2\%, Girişu de Criş: 5.8\%, Oradea: 0.5\%, Sîntandrei: $6.1 \%$, Toboliu: $3.2 \%$ ).

For degree of conservation and the actual state of nature reserve/Natura 2000 site it granted 0.7 point because of the high degree of anthropization. The vegetation belongs to Pannonian biogeographical region, in the past the area being dominated by swamps and wetlands,

\footnotetext{
${ }^{14}$ http://biodiversitate.mmediu.ro/rio/Natura 2000/static/pdf/rosci0267.pdf

${ }^{15} \mathrm{https}: / / \mathrm{www}$.econaturabihor.ro/wp-content/uploads/2013/02/Raport-expert-workshop2.pdf

${ }^{16} \mathrm{https}: / / w w w . e c o n a t u r a b i h o r . r o / w p-c o n t e n t / u p l o a d s / 2013 / 02 /$ Raport-expert-workshop3.pdf
} 
almost entirely drained by hydrotechnical works. The site is important for fish population and also for invertebrates. Characteristic are the hydrophilic habitats with Salix alba and Populus alba. Among protected species one can identify Gobio albipinnatus, Zingel streber, Cobitis taenia, Rhodeus sericeus amarus. The field survey identified other species such as Emys orbicularis, Lutra lutra, Castor fiber. ${ }^{17}$

For landscape value of natural protected area subcriterion the site granted 0.8 point on the basis of the high value of Crișului Repede, the meadow vegetation and because of a simple linear structure of components (figure 8).

For possibility of practicing different forms of tourism subcriterion the site granted 0.9 point. The most representative forms of tourism which can be practiced in the are being discovery and weekend tourism, sport angling.

Thus, the Crişului Repede Lower Meadow Natura 2000 ROSCI0104 site totals 4.4 points (table 1, figure 10).

\section{Alceu Valley Natura 2000 ROSPA0103 site}

For degree of representativity subcriterion the site granted 1 point because of the large territorial extension but also because the site overlap an other Natura 2000 (Crişului Repede Lower Meadow ROSCI0104 site).

For total surface of protected area subcriterion the site granted 0.9 point. The protected area covers 3,634 ha on the administrative territory of four communes (Girișu de Criș 25.9\%, Nojorid 9\%, Toboliu 16.5\%), just Sînnicolau Român commune not being part of O.M.A.

For degree of conservation and the actual state of nature reserve/Natura 2000 site it granted 1 point. The area is well known for its wetlands and open habitats represented by agricultural lands, orchards, pastures, anthropic lake, the course of Crișul Repede river. The site offers habitats for 22 species from Annex 1 Birds Directive 79/409/CEE which find here conditions for sheltering, feeding, nesting, breeding such as Falco vespertinus, Circus pygargus, Lanius minor, Lanius collurio, Circaetus gallicus, Aquila pomarina, Falco cherrug, Circus cyaneus, Himantopus himantopus, Tringa totanus, Platalea leucorodia, Nycticorax nycticorax. ${ }^{18}$

For landscape value the site granted 0.8 points. The score is related to the relatively simple organisation of natural components, with few landscape plans and a very high agricultural influence (figure 9).
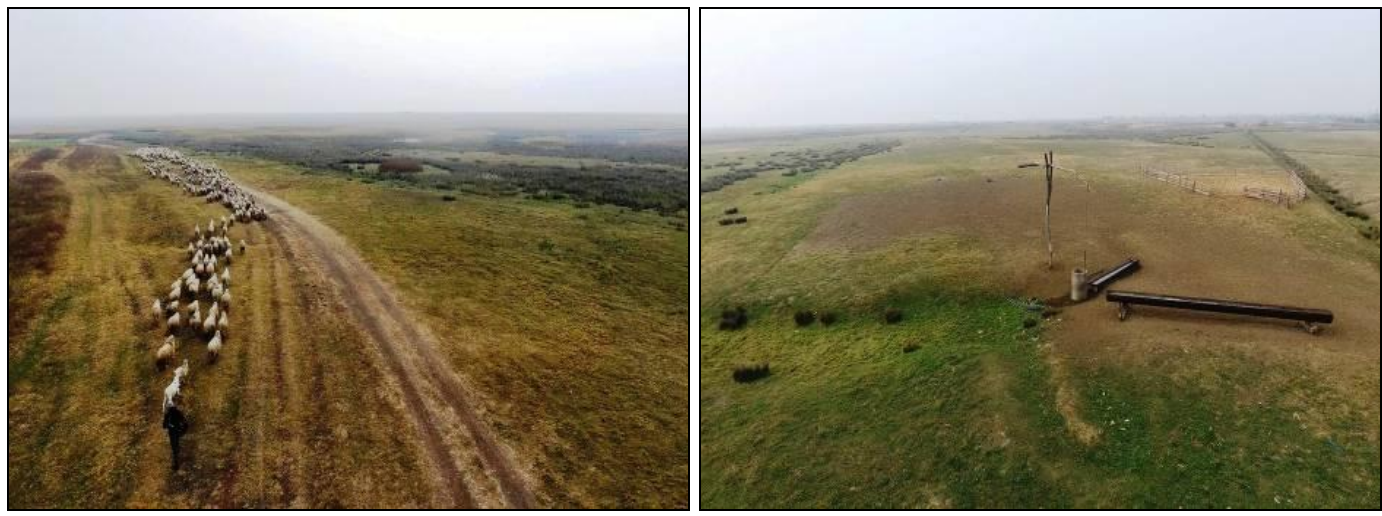

Figure 9. Alceu Valley Natura 2000 ROSPA0103 site

Thus, Alceu Valley Natura 2000 ROSPA0103 site totals 4.5 points (table 1, figure 10).

\footnotetext{
${ }^{17} \mathrm{http} / / /$ www.mmediu.ro/app/webroot/uploads/files/2016-03-22_PM_REG_ROSCI0104.pdf

${ }^{18}$ https://www.mmediu.ro/app/../2016-06-09_PM_si_R_ROSPA0103_Valea_Alceului.pdf, https://milvus.ro/wpcontent/uploads/2017/11/Plan_Management_ROSPA0103.pdf
} 
Analysing figure 10 one can notice that just one protected area (ROSCI0267 Red Valley site) reach the maximum score (5 points), according to Methodology, and the lowest score is obtained by ROSCI0098 Peţea Lake (3.5 points). The average score of O.M.A. is 4.4 (table 1) which can be considered from environmental point of view as being attractive from touristic point of view.

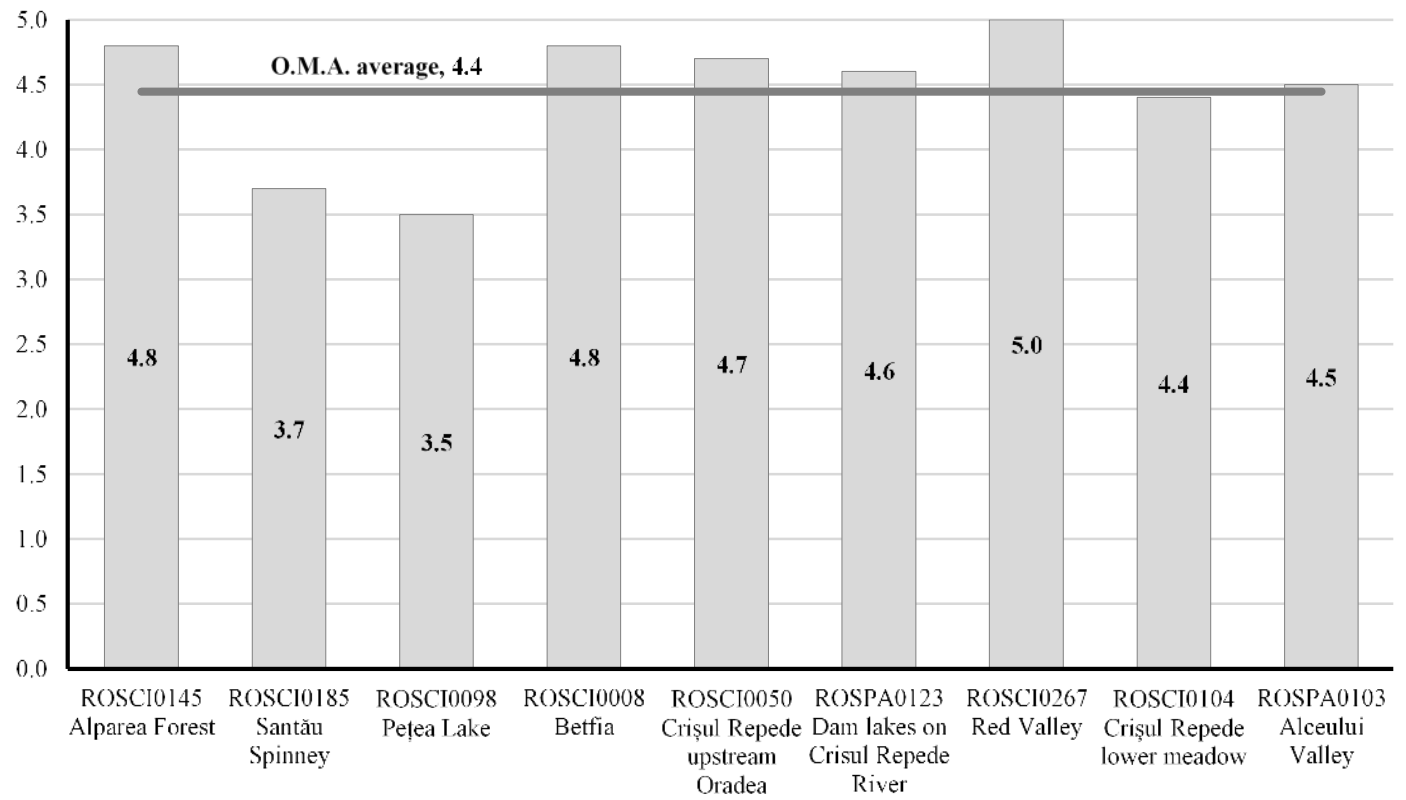

Figure 10. The score of Natura 2000 sites

according to Methodology of evaluation of touristic potential in territorial administrative units

At commune level, the protected areas from O.M.A. are consisted of 4 nature reserves, 9 Natura 2000 sites and two nature monuments, scoring between 1.8 and 3.5 points out of maximum 5 points (table 2). The lower score can be related to the fact that two communes (Biharia and Cetariu) doesn't have protected areas but both have, especially Cetariu, an important naturality potential which can attract tourists and different forms of weekend tourism (nature walks, cycling a.s.o.)

The highest attractivity score according to the presence of protected areas was gained by Sînmartin commune (3.5 points) on the basis of a mix of geomorphological, biogeographical and hydrological elements. Other communes have high attractivity scores, between 3-3.3 points, because of the association of plain-valley morphological elements and also because of the presence of flora and fauna elements, wetland associations. For such small-scale ecological systems one can notice an increasing interest for individual or organised forms of ecotourism, but the main requirement is not to disturb the existing ecological balance. The lower scores (1.8-2.3) can be related to areas without protected areas, the only exceptions being the corridor-like wetlands related to water courses, with own ecological identity. The vicinity of transport means can turn them proper for some forms of discovery tourism, but without a high flux of tourism.

Table 2. The score obtained by each commune of O.M.A.

related to degree of attractivity according to the existence of a protected areas

\begin{tabular}{|c|c|c|c|c|c|c|c|c|c|c|c|}
\hline Biharia & Borş & Cetariu & $\begin{array}{c}\text { Girişu de } \\
\text { Criş }\end{array}$ & Ineu & Nojorid & Oşorhei & Paleu & Sînmartin & Sîntandrei & Toboliu & $\begin{array}{c}\text { O.M.A. } \\
\text { average }\end{array}$ \\
\hline 0 & 3 & 0 & 3 & 1.8 & 3.3 & 3.3 & 3 & 3.5 & 1.8 & 2.3 & 2.27 \\
\hline
\end{tabular}




\section{Quality of environmental factors}

The quality of environmental factors cannot be found in the Methodology of evaluation of touristic potential, but we consider that represents, together with the climate, an important touristic resource and the presence of a less polluted environment can enhance the degree of attractivity of the rural of O.M.A.

One of the most important environmental elements affected by pollution is the air because of the very high values of the traffic. The rural of O.M.A. is crossed by a high density of road network, with an average value of $1.27 \mathrm{~km} / \mathrm{sqkm}$ (highest values are in Borş, $1,81 \mathrm{~km} / \mathrm{sqkm}$ and Sîntandrei, 1,91 km/sqkm). The road infrastructure is consisted of national/european roads DN 79 (E 671), DN 76 (E 79), DN1 (E 60), county and communal roads and unpaved roads. It is a fact that the urban population temporarily migrates towards the rural areas mainly because of the existence of water bodies, forests and natural protected areas.

Air quality, is monitorized mainly for Oradea. The monitoring system is made using the automated air quality monitoring network; airborne sediments measurement points; precipitation measuring points. Within Oradea the air quality indicators are generally good, the specific indicators - $\mathrm{CO}, \mathrm{SO}_{2}, \mathrm{NO}, \mathrm{NO}_{2}, \mathrm{NOx}, \mathrm{O}_{3}, \mathrm{MP}_{2.5}$ and $\mathrm{MP}_{10}$ (metal powders), BTX (benzene, toluene, xylene), meteorological parameters, precipitation quality - being in normal limits although there are some exceedings of Maximum Allowed Quantities. ${ }^{19,20,21}$

For examples the measured values for $\mathrm{CO}, \mathrm{NO}_{2}$, are generally within the accepted values but the measurements made at urban measuring points BH2 (industrial measurement point located in the yard of Elementary School, Episcopia Bihor neighbourhood, Matei Corvin street no. 106/A) and $\mathrm{BH} 3$ measuring point (traffic measuring point, located in Nufarul neighbourhood, next to McDonalds-drive in) are constant above the accepted legal values because of the heavy traffic. ${ }^{22}$

In the rural area of O.M.A. is measured the impact pollution using airborne sediments measuring points (Biharia, Tărian, Rontău, weather station Oradea) (figure 11). According to Bihor county Environmental Protection Agency there were no exceedings of this parameter. Related to airborne sediments $\left(\mathrm{MP}_{10}\right)$ the measurements made at $\mathrm{BH} 1$ point, in 2018, were just 27 case when the values exceeded the legal values, the cause being meteorological conditions. ${ }^{17}$

The quality of surface waters. On the basis of quality elements (biological, hydromorphological, chemical, physical) according to ecological and chemical state, were determined the following states:

- six quality states for rivers and natural lakes. Within O.M.A. just few brooks can be included in this category: Tăşad, Uileac, Sărand;

- five quality states for water bodies highly anthropically modified (here can be included the most parts of water bodies from O.M.A.);

- three quality states for artificial water bodies (channels).

On the territory of O.M.A., the main water courses are Crişul Repede and Peţa brook.

Crişul Repede is a highly modified water body which is monitorized in three points along on a length of $34.27 \mathrm{~km}$. According to indicator groups (oxygen regime, salinity, toxic pollutants, chemical indicators, biological indicators) the river water can be included at good ecological state with a high level of confidence (figure 11). ${ }^{23,24}$

Peţa brook, designated as water body highly modified was evaluated as having a medium ecologic potential, because of the negative impact of population (populated areas without sewage system, the poor technical state of the sewage pipes which transport the domestic waters from Sînmartin) (figure 11).

\footnotetext{
${ }^{19} \mathrm{http} / / / \mathrm{www} . c j b i h o r . r o / p d f / P l a n \% 20$ mentinere\%20calitate\%20aer\%20-\%202017.pdf

${ }^{20} \mathrm{https} / / /$ zmo.ro/strategiidedezvoltare/upload/doc/56-diagnostic\%20ZMO.pdf

${ }^{21} \mathrm{https} / /$ www.ebihoreanul.ro/stiri/ultima-or-31-41/oradea-sufocanta-masuratorile-arata-ca-in-ultimele-doua-luni-aerulorasului-a-fost-foarte-poluat-indeosebi-in-rogerius-140251.html

${ }^{22} \mathrm{http} / / /$ www.anpm.ro/documents/14457/3965235/Raport+preliminar+calitate+aer+2018.pdf/dcdefbee-613f-40ca-af4e-421e417dfcef

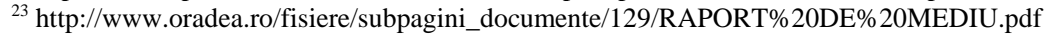

${ }^{24} \mathrm{https} / / / \mathrm{zmo} . \mathrm{ro} / \mathrm{strategiidedezvoltare/upload/doc/56-diagnostic \% 20ZMO.pdf}$
} 


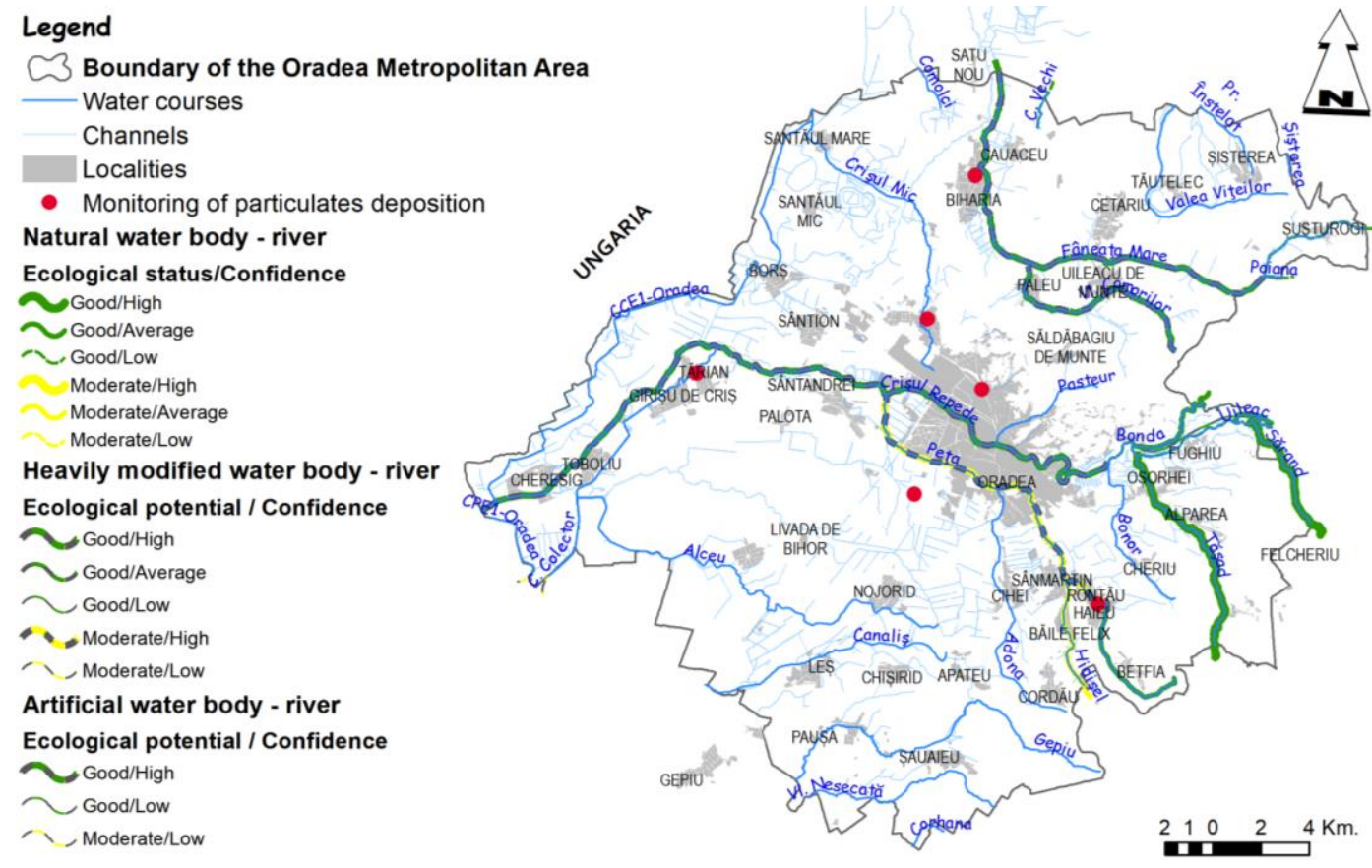

Figure 11. Water bodies quality monitoring and and air-borne sediments monitoring points (source, updated Management Plan for Crişuri hydrographic basin 2016-2021)

CCE1 and CPE1 channels and also the Collector Channel are considered artificial water bodies with a moderate ecologic potential and low confidence. ${ }^{25}$

The quality of underground waters. It is important because most of the rural population from O.M.A. use the underground water as water source. The underground water is also use as water source for activities related to tourism. The research of underground water quality is made on large hydrographic basins, on morphological units, and within these, on underground water bodies, monitorized using wells.

Related to the O.M.A., the specialists from "Romanian Waters" National Administration Crişuri Branch collected samples from Biharia F1, Girișu de Criș F1, Sînmartin F1MA, Sîntandrei F1MA, Nojorid F1MA wells and, analysing the hydrostatic level concluded, that within the rural areas of O.M.A. none of water bodies are in a poor quantitative state.

The nitrite $\left(\mathrm{NO}_{3}\right)$ indicators analysed for the free aquifer revealed medium values which exceeded the threshold values (established by G.O. 621/2014) resulting a low chemical state for the wells from Biharia and Girișu de Criș, areas under intense agricultural use.

The pressured underground water body (ROCR08) was monitorized in Cheresig 1AD well, without noticing exceedings of normal parameters (Dumitru and Botău, 2011; Dumitru et al., 2010). ${ }^{26}$

\section{CONCLUSIONS}

The administrative territory of O.M.A. is characterised by a high number of natural protected areas, 4 nature reserves, 9 Natura 2000 sites and 2 nature monuments (Ruscus aculeatus and water lily). The presence of these natural elements, in a certain degree of protection and the preservation of environmental factors (a less polluted environment) can contribute to the

\footnotetext{
${ }^{25} \mathrm{http} / /$ www.rowater.ro/dacrisuri/Planul\%20de\%20Management\%20Bazinal\%20Crisuri/PLANUL\%20DE\%20 MANAGEMENT\%20AL\%20BAZINULUI\%20CRISURI\%202016-2021/Plan\%20Management\%20s.h.\%20Crisuri \%202016-2021_vol.1.pdf

${ }^{26} \mathrm{https}: / / \mathrm{zmo} . \mathrm{ro} /$ strategiidedezvoltare/upload/doc/56-diagnostic\%20ZMO.pdf
} 
promotion of development potential of localities, to the increase of degree of attractiveness of the rural from O.M.A. and not least the increase of the living standards of the inhabitants.

The quantitative and qualitative analysis related to environmental touristic potential within the administrative units of O.M.A. reveals a mid degree of attractivity but compensate by a naturality potential, favourable for a weekend tourism. The high values of touristic attractivity are recorded in Sînmartin, 3.5 points, Nojorid and Oșorhei, 3.3 points because in this area there is a remarcable combination of geomorphological, hydrological and biogeographical elements.

\section{REFERENCES}

Borza, A. (1924). Floarea de Lotus de la Oradea. Revista Ştiinţifică V. Adamachi. 9(1) Iaşi.

Dumitru, M., Andrişca, S., Botău O., Vidican, A. (2010). Chimical status evaluation of phreatic underground waters in the Crisul Repede hidrographic basin. Analele Universităţii din Oradea, Seria Geografie, 20(2): 333-341.

Dumitru, M., Botău, O. (2011). Nitrate pollution in phreatic groundwater basin. Analele Universităţii din Oradea, Seria Geografie, 21(1): 30-38.

Grigoraş, G., Müller, T., Gagiu A., Şerban C., Bontaş I. (2015). Preliminary results regarding the present morphometric characters of thermal rudd, Scardinius racovitzai müller 1958 from Peţea spring natural reserve. Transylv. Rev. Syst. Ecol. Res. 17.2. The Wetlands Diversity. Sibiu.

Herman, G. V., Ilieș, D. C., Măduța, M. F., Ilieș, A., Gozner, M., Buhaș, R., Mihok-Geczi, I.-M.-T. (2016). Approaches regarding the importance of Natura 2000 sites' settings pupil's education through geography. Case study: Valea Roșie (Red Valley) Natura 2000, Bihor country, Romania. Journal of Geography, Politics and Society, 6(4): 57-62.

Ilieș, D. C., Baias, Ș., Buhaș, R., Ilieş, A., Herman, G. V., Gaceu, O., Dumbravă, R., Măduța, F. (2017a). Environmental education in protected areas. Case study from Bihor County, Romania. GeoJournal of Tourism and Geosites, 19(1): 126-132.

Ilieș, D. C., Herman, G. V., Ilieș, A., Baias, Ș., Dehoorne, O., Buhaș, S., Buhaș, Raluca, Josan, Ioana, Carțiș, H., Ungureanu, M. (2017b). Tourism and Biodiversity in Natura 2000 Sites. Case Study: Natura 2000 Valea Roșie (Red Valley) Site, Bihor County, Romania. Études caribéennes (37-38).

Ilieş, D. C., Buhaş, R., Ilieş, A., Morar, C., Herman, G. V. (2015). Nymphaea lotus var. Thermalis (Pârâul Peţea nature reserve), brand near extinction of the Băile Felix - Băile 1 Mai (Romania) spa tourism system. GeoJournal of Tourism and Geosites, 8(1): 107-117.

Linc R., Stașac, M. (2015). Protected areas of Bihor county (RO) between EU wishes and realities on the ground. The case study of the Peța brook nature reserve. Analele Universității din Oradea, fascicula Protecţia Mediului, 24: 181-194.

Marossy A. (1999). Unele observaţii asupra fenomenelor de colmatare şi eutrofizare a rezervaţiei naturale Pârâul Peţea. Nymphaea. Muz. Țării Crișurilor. Oradea. 139-144.

Oltean-Cosma, C. (1991). Nufărul termal de la Băile 1 Mai solicită ocrotire. Muzeul Țării Crișurilor. Oradea. 35.

Orășeanu, I., Malancu, Fl. (2017). Dynamics of the Felix - 1 Mai thermal aquifer (Bihor county, Romania). Nymphaea Folia naturae Bihariae. Muzeul Țării Crișurilor. Oradea. 44: 5-36.

Orăşeanu, I., Tenu, A, Iurkiewicz, A., Malancu, Fl. (2017). Studiu hidrogeologic privind situaţia actuală a resurselor sistemului geotermal Oradea-Băile Felix-1 Mai şi posibilităţile de protejare a sitului comunitar ROSCI 0098, Lacul Peța. RAPORT FINAL_FELIX_2017 (Rezumat). http://www.ahgr.ro/Proiecte/Felix-Oradea-2014.

Şoldea, V. (2003). Peţa şi nufărul termal. Editura Universităţii din Oradea.

Tătar C., Linc R., Dincă I., Bucur L., Stupariu, M., Stasac, M., Nistor, S. (2018). Nature-based suburban leisure opportunities within the Oradea Metropolitan Area. Analele Universităţii din Oradea, Seria Geografie, 28(2): 269-281.

Tuduce, A., Tomuleasa, I., Covaciu-Marcov S. D. (2001). Studiul populaţiei de Narcissus angustifolius CURT. din Pădurea Alparea, jud. Bihor. Analele Universității Oradea, Fascicula Biologie, 8:365-372.

Wendt, J. A., Buhaş, R., \& Herman, G. V. (2019). Experience of the Baile-Felix tourist system (Romania) for the protection and promotion of the grey seal as a brend on the Hel Peninsular (Poland). Baltic Region, 11(1), 109-136.

*** (2016), Plan de management al sitului de importanţă comunitară ROSCI0104 Lunca inferioară a Crişului Repede. http://www.mmediu.ro/app/webroot/uploads/files/2016-03-22_PM_REG_ROSCI0104.pdf.

*** (2016), Planul de Management al Sitului Natura 2000 ROSPA0103 Valea Alceului, https://www.mmediu.ro/app/../201606-09_PM_si_R_ROSPA0103_Valea_Alceului.pdf, https://milvus.ro/wp-content/uploads/2017/11/Plan_Manage ment_ROSPA0103.pdf.

*** (2016). Plan de Management Integrat al sitului Natura 2000 ROSCI0098 Lacul Pețea, Sit de Importanţă Comunitară şi al Rezervatiei 2177. Pârâul Peţea. http://www.mmediu.ro/app/webroot/uploads/files/2016-04-11_PM_ ROSCI0098_Petea.pdf.

*** (2016). Plan de Management Integrat al sitului Natura 2000 ROSCI0008 Betfia, Sit de Importanţă Comunitară şi al Rezervației 2187. Locul fosilifer de pe Dealul Şomleului. http://www.mmediu.ro/app/webroot/uploads/files/201604-11_PM_ROSCI0008_Betfia.pdf. 
**** (2016). Plan integrat de management al siturilor de importanţă comunitară ROSCI0050 Crişul Repede amonte de Oradea şi ROSPA0123 Lacurile de acumulare de pe Crişul Repede. http://www.mmediu.ro/app/webroot/uploads/ files/2016-03-22_PM_REG_ROSCI0050_ROSPA0123.pdf.

*** (2016). Planul de management actualizat al spaţiului hidrografic Crişuri 2016-2021. ABA Crişuri. http://www.rowater.ro/dacrisuri/Planul\%20de\%20Management\%20Bazinal\%20Crisuri/PLANUL\%20DE\%20MA NAGEMENT\%20AL\%20BAZINULUI\%20CRISURI\%202016-2021/Plan\%20Management\%20s.h.\%20Crisuri\% 202016-2021_vol.1.pdf.

*** (2016). Planul de management al sitului de importanţă comunitară ROSCI0145 Pădurea de la Alparea și al ariei naturale protejate de interes naţional 2.175. Pădurea cu narcise din Oşorhei. http://www.mmediu.ro/app/webroot/uploads/files/2015-0921_ROSCI0145_Padurea_Alparea_Plan_management.pdf.

*** (2017). Studiu privind impactul ecosistemelor din ariile protejate aflate în custodia Consiliului Judeţean şi a Muzeului Ţării Crişurilor asupra principalelor sectoare economice (EcoNatura), proiect derulat de CJ Bihor în cadrul Programului RO02-Biodiversitate și servicii ale ecosistemelor. https://www.econaturabihor.ro/wpcontent/uploads/2013/02/Raport-expert-workshop2.pdf. https://www.econaturabihor.ro/wp-content/uploads/2013/ 02/Raport-expert-workshop3.pdf.

**** Formularul standard Natura 2000 ROSCI0185 Păduricea de la Santău. http://biodiversitate.mmediu.ro/rio/Natura2000/ static/pdf/rosci0185.pdf.

*** Formularul standard Natura 2000; situl ROSCI0267 Valea Roşie. http://biodiversitate.mmediu.ro/rio/Natura 2000/static/pdf/rosci0267.pdf.

${ }^{* * * *}$ Metodologia privind evaluarea potenţialului turistic în unitaţile administrativ-teritoriale de bază. Anexa A. https://lege5.ro/../metodologia-pentru-analiza-potentialului-turistic-al-teritoriului-din-.

${ }^{* * *}$ Raport de mediu plan urbanistic general al municipiului Oradea. http://www.oradea.ro/fisiere/subpagini_documente /129/RAPORT\%20DE\%20MEDIU.pdf.

${ }^{* * *}$ Raport preliminar privind calitatea aerului în judeţul Bihor pentru anul 2018. http://www.anpm.ro/documents /14457/3965235/Raport+preliminar+calitate+aer+2018.pdf/dcdefbee-613f-40ca-af 4e-421e417dfcef.

*** Strategia de dezvoltare a Zonei Metropolitane Oradea. https://zmo.ro/strategiidedezvoltare/upload/doc/56diagnostic\%20ZMO.pdf.

http://www.cjbihor.ro/pdf/Plan\%20mentinere\%20calitate\%20aer\%20-\%202017.pdf.

https://www.ebihoreanul.ro/stiri/ultima-or-31-41/oradea-sufocanta-masuratorile-arata-ca-in-ultimele-doua-luni-aerulorasului-a-fost-foarte-poluat-indeosebi-in-rogerius-140251.html.

Submitted:

May 27, 2019
Revised:

June 15, 2019
Accepted and published online July 04, 2019 